\title{
QUALITY ASSESSMENT OF SERVICES PROVIDED BY WATER COMPANY
}

\begin{abstract}
The analyses of the opinions are one of the most important elements causing the improvement of the safety and dependability of the water supply system. In the thesis the result of research about satisfaction from operation of public water-supply systems by consumers using their services was presented. The research was performed by 225 respondents from the Podkarpacievoivodoship. In the research opinions on price and quality of water, inconveniences caused by lack of water supply and satisfaction from services were included. The respondents had no objections to the functioning of Customer Service Office, complaining only about slow or unkind services. The results of the survey show that the respondents positively evaluated the way of ensuring adequate pressure in the network. Most of the recipients had objections to the method of reading water meter, some of them would prefer more frequent meter readings, because so far they benefit from the settlement sums, also some respondents would like to change the readings for the telemetry. Suggestions of the respondents about the improvement of the technical condition of water supply system concern the introduction of testing water in household installations and establishing clear rules of water supply system functioning. Water supply company should regularly improve its services, so that undecided or dissatisfied people in a subsequent study will be satisfied with the quality of services.
\end{abstract}

Keywords:consumer survey, water supply, operation of water network.

\section{INTRODUCTION}

Control of the quality of supplied water to recipients was introduced with the development of water companies. The main reason for this process were numerous epidemics caused by poor water quality. Water quality depends on many factors, including the source and intake method, as well as its treatment. It is also not without significance the sanitary condition of water storage tanks and water supply networks, water supply connections and internal installations. The water should meet certain standards, due to the fact that water companies are obliged to control water composition and its properties, as to deliver it without interruption and with proper pressure.Currently supervision covers water intake, water treatment and distribution to customers. This control was transformed into a quality management system standardized by the ISO

${ }^{1}$ Dr inż. Katarzyna Pietrucha-Urbanik, Politechnika Rzeszowska, Wydział Budownictwa, Inżynierii Środowiska i Architektury, al. Powstańców Warszawy 6, 35-959 Rzeszów, autor korespondencyjny: e-mail:kpiet@prz.edu.pl

${ }^{2}$ Mgr inż. Anna Trojnar, Politechnika Rzeszowska, Wydział Budownictwa, Inżynierii Środowiska i Architektury, al. Powstańców Warszawy 6, 35-959 Rzeszów 
standards which require the enterprises to conduct the surveys of the users. Studying the survey the company has an opinion on what the customers are dissatisfied with, what need to be improved and what should not be done to maintain high level of customer satisfaction. Water companies conduct such research more and more often because thanks to its results they can find a lot of information about the water supply systems, which can help improve the quality of services ${ }^{3}$ as in future to plan potential modernization of water network $^{4}$ and maintain the reliable functioning of water network ${ }^{5}$. Surveys are a primary source of information for water companies and can be performed using various techniques and research tools which have been described in numerous publications ${ }^{6,7}$. In the work ${ }^{8}$ the issues of water supply in a crisis situation and assessment of such situation by water consumers were presented.

Surveys of water supply users, which relate to the analysis of water supply failures are presented in numerous works, among others ${ }^{9,10}$.

The conducted survey has been made to examine the satisfaction of the residents of Podkarpacie with the quality of services provided by the water company.

The forms of survey were distributed among randomly selected people living in the examined area ofPodkarpackie province. Research was conducted personally among the inhabitants of the blocks and houses.Non random sampling was applied. The survey consisted of 30 questions, 4 of them were demographic questions, while the remaining 26 - substantive questions. There were 23 questions of single or multiple choice and 3 open questions. Demographic questions were related to gender, age, education and place of residence of the respondents. The majority of respondents willingly answered the closed questions, unfortunately, a significant part of respondents skipped the open questions placed in the form. The questionnaire was anonymous. The study was conducted so that in

\footnotetext{
${ }^{3}$ Kwietniewski M., Rak J., Niezawodność infrastruktury wodociągowej i kanalizacyjnej w Polsce (Reliability of water and sewerageinfrastructure in Poland). PAN, Warszawa 2010;

${ }^{4}$ Studziński A., Pietrucha-Urbanik K., Preventive maintenance and reliability of water supply system elements. „CzasopismoInżynieriiLądowej, ŚrodowiskaiArchitektury - Journal of Civil Engineering, Environment And Architecture, JCEEA”, 2015, No 3/I, pp. 429-436. DOI: 10.7862/rb.2015.126;

${ }^{5}$ Rak J., Pietrucha-Urbanik K., New directions for the protection and evolution of water supply systems - smart water supply. „CzasopismoInżynieriiLądowej, ŚrodowiskaiArchitektury - Journal of Civil Engineering, Environment And Architecture, JCEEA", 2015, No 3/I, pp. 365-373. DOI: 10.7862/rb.2015.121;

${ }^{6}$ Goodyear M., Qualitative research, ESOMAR, London 1998;

${ }^{7}$ Kaden R. J., Badaniamarketingowe (Marketing research). PWE, Warszawa 2008;

${ }^{8}$ Rak J., Pietrucha-Urbanik K., Badanie sondażowe związane $\mathrm{z}$ brakiem dostawy wody wodociągowej w sytuacjach kryzysowych (Surveyrelated to lack of watersupplywater in crisissituations), „Instal”, 2016, No 2, pp. 54-58;

${ }^{9}$ Rak J., Analiza opinii konsumentów wody do spożycia korzystających z wodociągu publicznego miasta Rzeszowa (Analysis of consumerreviews of drinkingwaterusing the public water network of Rzeszowcity), „Technologia Wody”, 2012, No 1, pp. 30-34;

${ }^{10}$ Rak J., Tułacz E., Analiza opinii konsumentów wody do spożycia korzystających z wodociągu publicznego na terenie województwa podkarpackiego (Analysis of consumerreviews of drinkingwaterusingwater form network in Podkarpacie). „Zeszyty Naukowe Politechniki Rzeszowskiej Budownictwo i Inżynieria Środowiska”, 2007, No 3, pp. 123-136;
} 
the age structure and the gender participated the comparable number of respondents, as recommended in many works ${ }^{11,12}$. Marketing research is very important in the development of companies. It is necessary to obtain and to maintain a high position in the market. Conducting surveys can determine the degree of customer satisfaction with services of water company ${ }^{13}$, through selected indicators of service level evaluation ${ }^{14}$.

The subject of analysis was to find out people's opinions on the operation of public water supply systems, which helped evaluate the general conditions of water supply.

\section{ASSESSMENT OF THE QUALITY OF SERVICES PROVIDED BY THE WATER COMPANY}

2.1. Important characteristics of tap water

The respondents participating in the survey were asked to rank the five qualities of tap water, according to the importance of those qualities for them. The respondents were given five features characterizing work of public water supply network and were asked to arrange them in the order of the most important to the least important. The results are shown in Figure 1.

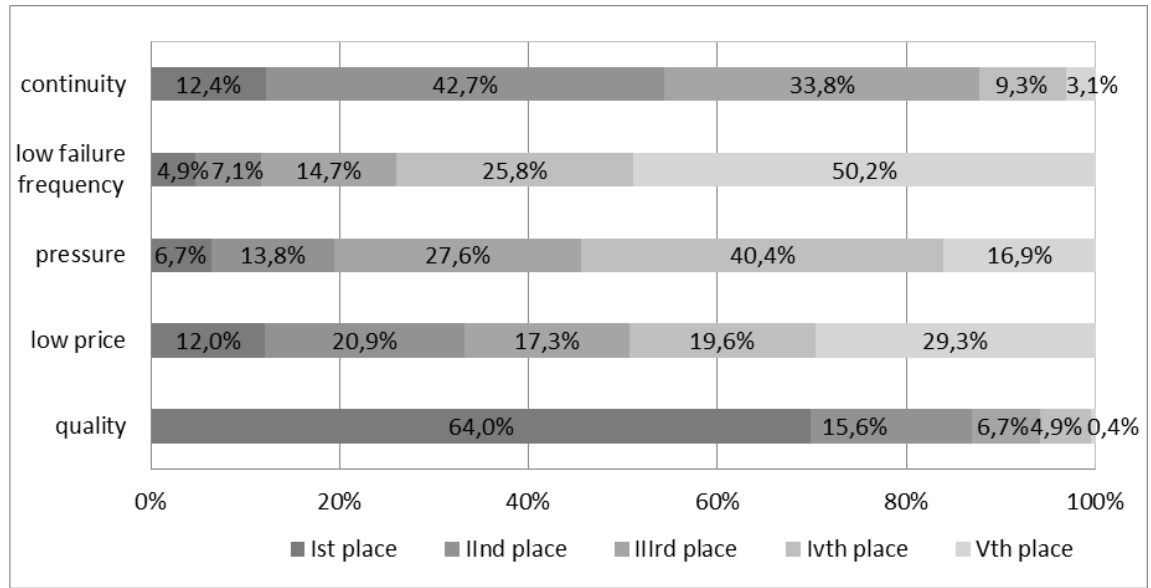

Fig.1. Important characteristics of tap water according to the respondents.

\footnotetext{
${ }^{11}$ Hague P., Badania marketingowe. Planowanie, metodologia $i$ ocena wyników (Marketing research. Planning, methodology and evaluation of results). HELION, Gliwice 2006;

${ }^{12}$ Kaczmarczyk S., Badania marketingowe. Metody i techniki (Marketing research. Methods and techniques). PWE, Warszawa 2003;

${ }^{13}$ Shinde V.R., Hirayama N., Itoh S., Development of evaluation model for consumers' satisfaction of water supply service. „WIT Transactions on Ecology and The Environment”, 2014, Vol 178, pp. 215-223, doi:10.2495/13WS130181;

${ }^{14}$ Itoh S., Shiro S., Hirayama N., Echigo S., Ohkouchi Y., Psychosocial considerations on strategies for improving customers' satisfaction with tap water based on casual modelling, „Journal of Japan Water Works Association”, 2007, No 4, pp. 25-37;
} 
The most significant aspect according to the respondents is water quality. $64 \%$ of the respondents placed it on the first and thus the most important place. The lowest in the hierarchy of importance were low failure frequency and low price. It can be concluded that the consumers tend to put the quality over the price of $1 \mathrm{~m}^{3}$ of tap water. Depending on the age of the respondents, different sense of value of the individual characteristics of water is noticeable. The percentage of assessment of particular water characteristics, according to age group, is presented in Table 2.

Table 2. List of significant characteristics of tap water, according to the age of the respondents, in terms of the order of assigning ratings.

\begin{tabular}{|c|c|c|c|c|c|c|c|}
\hline \multirow{2}{*}{ Age of respondents } & \multirow{2}{*}{ Specification } & \multicolumn{5}{|c|}{ Gradingscale } & \multirow{2}{*}{ Total } \\
\hline & & 1 & 2 & 3 & 4 & 5 & \\
\hline \multirow{5}{*}{$18-27$} & quality & $\underline{86,0 \%}$ & $7,0 \%$ & $3,5 \%$ & $1,8 \%$ & $1,8 \%$ & $100 \%$ \\
\hline & lowprice & $1,8 \%$ & $22,8 \%$ & $19,3 \%$ & $24,6 \%$ & $31,6 \%$ & $100 \%$ \\
\hline & continuity of supply & $7,0 \%$ & $47,4 \%$ & $33,3 \%$ & $5,3 \%$ & $7,0 \%$ & $100 \%$ \\
\hline & lowfailurefrequency & $3,5 \%$ & $5,3 \%$ & $14,0 \%$ & $36,8 \%$ & $40,4 \%$ & $100 \%$ \\
\hline & pressure & $1,8 \%$ & $17,5 \%$ & $29,8 \%$ & $31,6 \%$ & $19,3 \%$ & $100 \%$ \\
\hline \multirow{5}{*}{$28-37$} & quality & $\underline{66,0 \%}$ & $20,0 \%$ & $4,0 \%$ & $10,0 \%$ & $\mathbf{0 , 0 \%}$ & $100 \%$ \\
\hline & lowprice & $18,0 \%$ & $16,0 \%$ & $36,0 \%$ & $10,0 \%$ & $20,0 \%$ & $100 \%$ \\
\hline & continuity of supply & $12,0 \%$ & $40,0 \%$ & $28,0 \%$ & $20,0 \%$ & $0,0 \%$ & $100 \%$ \\
\hline & lowfailurefrequency & $4,0 \%$ & $8,0 \%$ & $8,0 \%$ & $28,0 \%$ & $52,0 \%$ & $100 \%$ \\
\hline & pressure & $0,0 \%$ & $16,0 \%$ & $24,0 \%$ & $32,0 \%$ & $28,0 \%$ & $100 \%$ \\
\hline \multirow{5}{*}{$38-47$} & quality & $\underline{71,4 \%}$ & $20,4 \%$ & $8,2 \%$ & $\mathbf{0 , 0 \%}$ & $0,0 \%$ & $100 \%$ \\
\hline & lowprice & $\overline{16,3 \%}$ & $20,4 \%$ & $8,2 \%$ & $36,7 \%$ & $18,4 \%$ & $100 \%$ \\
\hline & continuity of supply & $12,2 \%$ & $59,2 \%$ & $28,6 \%$ & $0,0 \%$ & $0,0 \%$ & $100 \%$ \\
\hline & lowfailurefrequency & $0,0 \%$ & $0,0 \%$ & $12,2 \%$ & $22,4 \%$ & $65,3 \%$ & $100 \%$ \\
\hline & pressure & $0,0 \%$ & $0,0 \%$ & $42,9 \%$ & $40,8 \%$ & $16,3 \%$ & $100 \%$ \\
\hline \multirow{5}{*}{$48-57$} & quality & $72,7 \%$ & $15,2 \%$ & $12,1 \%$ & $\mathbf{0 , 0 \%}$ & $0,0 \%$ & $100 \%$ \\
\hline & lowprice & $15,2 \%$ & $30,3 \%$ & $9,1 \%$ & $\mathbf{0 , 0 \%}$ & $45,5 \%$ & $100 \%$ \\
\hline & continuity of supply & $12,1 \%$ & $9,1 \%$ & $54,5 \%$ & $15,2 \%$ & $9,1 \%$ & $100 \%$ \\
\hline & lowfailurefrequency & $0,0 \%$ & $24,2 \%$ & $15,2 \%$ & $24,2 \%$ & $36,4 \%$ & $100 \%$ \\
\hline & pressure & $0,0 \%$ & $21,2 \%$ & $9,1 \%$ & $60,6 \%$ & $9,1 \%$ & $100 \%$ \\
\hline \multirow{5}{*}{$>57$} & quality & $\underline{55,6 \%}$ & $19,4 \%$ & $8,3 \%$ & $16,7 \%$ & $\mathbf{0 , 0 \%}$ & $100 \%$ \\
\hline & lowprice & $\overline{13,9 \%}$ & $16,7 \%$ & $8,3 \%$ & $22,2 \%$ & $38,9 \%$ & $100 \%$ \\
\hline & continuity of supply & $16,7 \%$ & $44,4 \%$ & $30,6 \%$ & $8,3 \%$ & $0,0 \%$ & $100 \%$ \\
\hline & lowfailurefrequency & $8,3 \%$ & $2,8 \%$ & $27,8 \%$ & $5,6 \%$ & $55,6 \%$ & $100 \%$ \\
\hline & pressure & $5,6 \%$ & $16,7 \%$ & $25,0 \%$ & $47,2 \%$ & $5,6 \%$ & $100 \%$ \\
\hline
\end{tabular}

In the table 2 the maximum percentages in different age groupswere underlined and marked in bold the lowest. It is noticeable that in each age group, the most important of water characteristics is its quality. The greatest attention to this parameter pay the people aged between 18-27(86\%). In the most age ranges the lowest in the hierarchy of importance was placed low failure frequency, except the age group of 48-57 where it was small price $(45,5 \%)$ 


\subsection{Ensuring adequate pressure}

According to the Regulation of the Minister of Infrastructure on technical conditions for buildings and their location "water pressure in the water supply system in the building, excluding fire hydrants, before each water intake point, should be of not less than 0.05 MPa (0,5 bar) and not more than $0,6 \mathrm{MPa}(6$ bars)." Sometimes the problem is to ensure suitable pressure. It can occur, for example, during the largest water consumption. For information on users satisfaction with the water pressure, the respondents were asked to assess it using a five-point scale.

The majority of the respondents $(85,4 \%)$ is satisfied with water pressure ensured by the company. However, there were some people who are not satisfied $(13,8 \%)$, which may be caused by various factors. Very low satisfaction with the pressure was expressed by the residents of newly constructed or continuously developing housing estates which may be caused by continuous enlargement of those estates.

\subsection{Meter readings}

A reading of the water meter the water supply company can make manually, it can be made by the recipients and send by the internet, phone or mail data transfer and by collecting information using the telemetry. In households of the examined respondents a reading is made by various ways.In majority of the respondents households $(60 \%)$ a reading of the meters is made manually by a visit of the employee ofthe water supply company. Nearly $1 / 5(19,1 \%)$ of the respondents provide data by the telephone or personally, at every 10 th person $(10,7 \%)$ a reading is made by the telemetry. The answer "others" was marked by $4,4 \%$ of the respondents, that means the lump sum settlement.

Another question in the questionnaire concerned satisfaction of the way of billing customers for consumed water. About $92 \%$ of the respondents are satisfied with the current method of the water meter reading and only $8 \%$ expressed dissatisfaction. These were people whose reading is made manually $(77,8 \%)$ or by lump sum $(22,2 \%)$. The recipients dissatisfied with the way of water meter reading have been asked to name the causes of their dissatisfaction and/or a method that would change their negative attitude to the subject.Answers about the reasons for dissatisfaction with the way of the water meter reading are as following: changing to radio reading - telemetry $(72,2 \%)$, changing to a monthly readings $(22,2 \%)$, lack of culture of the employees that read the meter $(5,6 \%)$. Justification of the provided answers of dissatisfaction was following: the respondents indicated that it would be more convenient to read via the telemetry because not always there is someone in the house and frequently the water meter is located in an inaccessible place. Users also drew attention to the fact that in an annual settlement, which is send by the housing association, is not given the amount of monthly bills and an equalization coming at the end of the year is often very high. Such problems were indicated in works, concerning smart system metering ${ }^{15}$.

\footnotetext{
${ }^{15}$ Rak J., Pietrucha-Urbanik K., New directions for the protection and evolution of water supply systems - smart water supply. „CzasopismoInżynieriiLadowej, ŚrodowiskaiArchitektury - Journal of Civil Engineering, Environment And Architecture, JCEEA", 2015, No 3/I, pp. 365-373. DOI: 10.7862/rb.2015.121;
} 


\subsection{Quality assessment of provided services}

Assessment of the water company activities was made using the question included in the questionnaire, which was: How do you assess quality of services provided by the water supply company? Initial analysis shows that almost $59,0 \%$ of the respondents are satisfied with the activities of the water supply company which provides services. Dissatisfied is only $0.9 \%$, while a very large group of the respondents $(40,44 \%)$ are people who assess the quality of services as the average. In the assessment of the quality of services provided by the water supply company, taking into account the sex of the respondents, more men are satisfied $(61,5 \%)$ than women $(56,2 \%)$, also there are more undecided women $(43,8 \%)$ than men $(36,5 \%)$.

Considering the age of the respondents, dissatisfied with the quality of services were only those above 57 years of age $(5,5 \%)$. In the age group of $48-57$ dominate those respondents who consider the quality of services provided by the water supply company as high $(69,7 \%)$. Among the respondents falling to the age group of $38-47$, the answers were divided only into two opinions.

In this age range the quality of service was evaluated as average by $53,1 \%$ of the respondents and as high by $46,9 \%$. In comparison to other groups the youngest age group $(18-27)$ is the most satisfied with the provided services $(57,9 \%)$, but in that group there is also the large number of undecided respondents $(42,1 \%)$. The greatest satisfaction with the quality of services shows the age group of $48-57(84,9 \%)$, while the lowest $37-48$ $(46,9 \%)$

Another question concerned the operation of Customer Service Office. The results of researchindicated that $43,1 \%$ of the respondents had contact with Customer Service Office in the water company, while the rest, $56,9 \%$ of the respondents, did not.

The respondents who had contact with the Customer Service Office were asked to assess work of its employees. Most respondents indicated positive qualities, but there were also those who assessed work of the office negatively. The largest part of the respondents pointed out that the office staff were polite $(80,4 \%)$ and competent $(70,1 \%)$, while among the most negative opinions appearedopinions about the slowness $(10,3 \%)$ and the rudeness $(9,3 \%)$.

\section{SUGGESTIONS OF PUBLIC WATER NETWORK CONSUMERS FOR} IMPROVING THE QUALITY OF SERVICES

Respondents who took part in the study were given the opportunity to share their own ideas about improving the public water functioning through answering the following question: What would you improve or change in the operation of public water supply system? About $49 \%$ of surveyed respondents answered this question.

Categories of answers regarding suggestions for public water supply system operation are shown in Table 1. 
Table 3. Categories ofanswers regarding customers suggestions for public water supply system operation.

\begin{tabular}{lrc}
\hline No & Categories of responses & Number of people \% \\
\hline 1 & No objections & 36,9 \\
\hline 2 & Improving the quality of supplied water & 19,8 \\
\hline 3 & Information on interruption placed in visible places/Failures \\
& removal during night hours & 17,1 \\
\hline 4 & Changing the meter reading & 9,9 \\
\hline 5 & Lowering water and services price & 9,0 \\
\hline 6 & Ensuring adequate pressure & 5,4 \\
\hline 7 & Inproving the technical condition of water supply networks & 4,5 \\
\hline 8 & Clarification of regulations & 2,7 \\
\hline 9 & Reliable information about problems with maintaining adequate & 1,8 \\
\hline 10 & water quality & 0,9 \\
\hline
\end{tabular}

Most of the respondents who have benefited from the opportunity of giving their suggestions about the public water supply system operation claimed that they have no objection to the water company $(36,9 \%)$. Nearly $20 \%$ of the respondents suggested the improvement of water quality and over $17 \%$ suggested better information about interruptions in water supply and to move the interruptions in water supply for the night hours when the demand for tap water is smaller. A lot of the respondents $(9,9 \%)$ are not satisfied with the way of the meter reading. Among them, 7,2\% would prefer more frequent readings and therefore they probably use lump sum payment and $2,7 \%$ would like to change the readings for the telemetry. Quite often the following categories were indicated: the decrease in the water price and price of the services offered by the water supply company and ensuring an adequate pressure, which, according to the respondents, is inadequate at certain time of day (usually in the evenings) or in particular seasons (especially in summer). From all the statements it is worth to quote some of them, which draw the attention to problems in the operation of public water supply systems:

- developing the clear and transparent plan for network modernization and making changes for improving the water quality distributed tothe recipients,

- replacing water supply pipes and connections with the new ones and changing the way of water meter reading for the telemetry,

- improving the water quality, monthly readings and bills for water, reducing prices for water andintroducingwater quality examination in residential installation.

- improving the technical condition of the water supply system, primarily replacement ofcorrosive materials.

- changing or improving the method of informing about interruptions in the water supply, changing the hours of failure removal for night hours.

- change in notifying the residents about interruptions in water supply by, for example, displaying information in more visible places.

- improving the pressure in the water supply system in summer.

- improving the quality of tap water, especially its colour. 
- clarification of regulations, as in some cases there are discrepancies in the agreement between the water supply company and the recipients.

- change in the cost of connecting to the water network and suggestion that it should be sponsored by the water supply company.

These statements draw special attention to the fact that users are aware that the quality of tap water is also dependent on the state of the network and installations and not just on the water treatment plant. Water pollution is primarily influenced by the network conditions. There is very high risk of corrosion, among others, when the water consumption is small. Also very important are the pipes diameter and the stability of water flowing through pipes. In the article ${ }^{16}$ about corrosive processes in copper systems and their impact on water quality, it was concluded that the corrosion problem cannot be completely eliminated, however, the consequences can be reduced through the use of preventive measures, which are, among others, the use of approved and proven materials, precisely madeinstallation, accurate pipes rinsing, mounting filters and the use of inhibitors.

\section{CONCLUSIONS}

The study shows the opinions expressed by the Podkarpacie residents about the quality of service provided by the Customer Service Office, as well as about the inconvenience of interruptions in water supply.

The survey shows that the recipients put the most emphasis on the quality of tap water and then on water price or continuity of water supply.

In order to constantly improve the quality of services offered to the users of public water supply system and to increase customers satisfaction, the water companies should perform continuous monitoring of satisfaction by conducting surveys among the water consumers.

Survey results will help to adjust the water supply conditions to consumers in order to ensure the effective functioning of services.

The presented water consumers survey will provide information about the quality level of provided services and will help in development of water safety plan, which constitutes an important element of the proper functioning of water supply systems.

\section{REFERENCES}

[1] Goodyear M., Qualitative research, ESOMAR, London 1998;

[2] Hague P.,Badania marketingowe. Planowanie, metodologia i ocena wyników (Marketing research. Planning, methodology and evaluation of results). HELION, Gliwice 2006;

\footnotetext{
${ }^{16}$ Papciak D., Kaleta J., Puszkarewicz A., Procesy korozyjne w instalacjach miedzianych a jakość wody (Corrosionprocesses in copperinstallations and waterquality), „Zeszyty Naukowe Politechniki Rzeszowskiej Budownictwo i Inżynieria Środowiska”, 2007, No 1, pp. 73 -86;
} 
[3] Itoh S., Shiro S., Hirayama N., Echigo S., Ohkouchi Y., Psychosocial considerations on strategies for improving customers' satisfaction with tap water based on casual modelling,,Journal of Japan Water WorksAssociation", 2007, No 4, pp. 25-37;

[4] Kaczmarczyk S., Badania marketingowe. Metody $i$ techniki (Marketing research. Methods and techniques). PWE, Warszawa 2003;

[5] Kaden R. J., Badania marketingowe (Marketing research). PWE, Warszawa 2008;

[6] Kwietniewski M., Rak J., Niezawodność infrastruktury wodociagowej $i$ kanalizacyjnej w Polsce (Reliability of water and sewerageinfrastructure in Poland). PAN, Warszawa 2010;

[7] Papciak D., Kaleta J., Puszkarewicz A., Procesy korozyjne $w$ instalacjach miedzianych a jakość wody (Corrosionprocesses in copperinstallations and waterquality), „Zeszyty Naukowe Politechniki Rzeszowskiej Budownictwo i Inżynieria Środowiska", 2007, No 1, pp. 73-86;

[8] Rak J., Analiza opinii konsumentów wody do spożycia korzystajacych z wodociagu publicznego miasta Rzeszowa (Analysis of consumerreviews of drinkingwaterusing the public water network of Rzeszowcity), „Technologia Wody", 2012, No 1, pp. 30-34;

[9] Rak J., Pietrucha-Urbanik K., Badanie sondażowe zwiazane z brakiem dostawy wody wodociagowej w sytuacjach kryzysowych (Surveyrelated to lack of watersupplywater in crisissituations), „Instal”, 2016, No 2, pp. 54-58;

[10] Rak J., Pietrucha-Urbanik K., New directions for the protection and evolution of water supply systems - smart water supply. „CzasopismoInżynieriiLądowej, ŚrodowiskaiArchitektury - Journal of Civil Engineering, Environment And Architecture, JCEEA”, 2015, No 3/I, pp. 365373. DOI: $10.7862 / \mathrm{rb} .2015 .121$;

[11]Rak J., Tułacz E., Analiza opinii konsumentów wody do spożycia korzystajacych $z$ wodociagu publicznego na terenie województwa podkarpackiego (Analysis of consumerreviews of drinkingwaterusingwater form network in Podkarpacie). „Zeszyty Naukowe Politechniki Rzeszowskiej Budownictwo i Inżynieria Środowiska", 2007, No 3, pp. 123-136;

[12] Shinde V.R., Hirayama N., Itoh S., Development of evaluation model for consumers' satisfaction of water supply service. „WIT Transactions on Ecology and The Environment", 2014, Vol 178, pp. 215-223, doi:10.2495/13WS130181;

[13] Studziński A., Pietrucha-Urbanik K., Preventive maintenance and reliability of water supply system elements. „CzasopismoInżynieriiLądowej, ŚrodowiskaiArchitektury - Journal of Civil Engineering, Environment And Architecture, JCEEA", 2015, No 3/I, pp. 429-436. DOI: 10.7862/rb.2015.126; 


\section{OCENA JAKOŚCI ŚWIADCZONYCH USLUG PRZEZ PRZEDSIĘBIORSTWO} WODOCIĄGOWE

Badania sondażowe są jednym $\mathrm{z}$ ważniejszych elementów prowadzących do poprawy bezpieczeństwa funkcjonowania i niezawodności systemu zaopatrzenia $\mathrm{w}$ wodę. $\mathrm{W}$ pracy przedstawiono wyniki badań przeprowadzonego sondażu, na temat zadowolenia $\mathrm{z}$ funkcjonowania wodociągów publicznych przez konsumentów korzystających z ich usług. $\mathrm{W}$ badaniu udział wzięło 225 respondentów z województwa podkarpackiego. Badanie objęło opinie na temat cen i jakości wody, uniedogodnień spowodowanych brakiem w dostawie wody oraz poziomu satysfakcji z usług wodociągowych. Przeprowadzone badania pozwalają określić orientacyjnie jakie odczucia mają mieszkańcy Podkarpacie względem jakości wody, jej ceny, jakości obsługi w Biurze Obsługi Klienta, a także uciążliwości związanych z przerwami w dostawie wody. Ankietowani pozytywnie ocenili zapewnienie odpowiedniego ciśnienia $\mathrm{w}$ sieci wodociągowej. Respondenci nie mieli zastrzeżeń do funkcjonowania Biura Obsługi Klienta, uskarżając się jedynie w niewielkim stopniu na powolną lub nieuprzejmą obsługę. Ankietowani często wskazywali również niezadowolenie ze sposobu odczytu wskazań wodomierza, część z nich preferowałoby częstsze odczyty licznika, ponieważ dotychczas korzystają oni $\mathrm{z}$ rozliczeń ryczałtowych, niektórzy $\mathrm{z}$ respondentów chciałoby zmienić odczyty na telemetrię. Z sondażu wynika, że odbiorcy największy nacisk kładą na jakość wody wodociągowej, a w następnej kolejności dopiero na jej cenę czy też ciągłość dostawy. W celu ciągłego podnoszenia jakości usług oferowanych użytkownikom wodociągów publicznych oraz wzrostu ich satysfakcji, przedsiębiorstwa wodociągowe powinny prowadzić ciągły monitoring zadowolenia poprzez przeprowadzanie wśród nich sondaży.

Słowa kluczowe:badania sondażowe, zaopatrzenie w wodę, funkcjonowanie wodociągów.

DOI:10.7862/rz.2016.hss.48

Przesłano do redakcji: styczeń 2016

Przyjęto do druku: wrzesień 2016 